\title{
Middle Jurassic sequence stratigraphic characteristics in Longdong coalfield
}

\author{
Tai $\mathrm{Xu}^{1, *}$, Shuang $\mathrm{Li}^{1}$, Fengfeng Yang ${ }^{1}$, Jufeng Zhang ${ }^{1}$, and Xiulan Zhu ${ }^{1}$ \\ ${ }^{1}$ School of Energy Engineering, Long Dong University, 745000, China
}

\begin{abstract}
Stratigraphic sequence contrast and sequence stratigraphic framework are of great significance for the sedimentary phase and sedimentary systems of coal-accumulating basin. In the coal-bearing basin, the variation of the flooding surface controls the migration law of the coal-concentrating centres within the range. Therefore, the sequence comparison work is crucial to find favorable coal-collecting areas. In addition, studying the position of the coal seam in the sequence stratigraphic framework and carrying out the sequence comparison work in the lateral direction can effectively track the change of the position of the coal seam in the sequence stratum and summarize the law of coal seam accumulation and occurrence, which can be better to plan and guide the exploration and development of coal resources in Longdong coalfield.
\end{abstract}

The Longdong area of Gansu Province, including the areas under the jurisdiction of Pingliang City and Qingyang City, east of Liupan Mountain, is located in the southwestern part of the Ordos Basin. It is part of the Ordos giant Mesozoic basin and is rich in coal resources. According to the survey, the proven coal resource reserves in the eastern part of the country are 5.4 billion tons, accounting for $59 \%$ of the province's proven coal resource reserves. The predicted coal resources in the eastern region are 136.3 billion tons, accounting for $95 \%$ of the province's predicted coal resources. The Longdong area is the focus of coal geological exploration in Gansu Province in the future. In recent years, the exploration of coal resources in the south of Zhengning and the central part of Ning County has achieved fruitful results, further confirming the prospect of coal geological exploration in the Longdong area ${ }^{[1]}$.

In this paper, relevant geological data were collected through field survey of the Middle Jurassic Squence Stratigraphy in the Longdong area. Through careful comparison and analysis ${ }^{[2]}$, the vertical and plane distribution of coal seams in the sequence stratigraphic framework are clarified, which has certain guiding significance for future geological exploration and coal resource development.

\section{Research area sequence and system domain interface identification principle}

The sequence is a set of relatively integrated, connected stratigraphic units, bounded by unconformity and laterally comparable integration surfaces. The stratigraphic unit between sequence bottom boundary and the first flooding surface in the sequence is the initial filling system domain. The initial marine-flooding surface and the maximum flood surface is the basin expanding systems tract. The maximum flood surface and the sequence top boundary is the basin reducing systems tract. The Ordos Basin is a large inland sedimentary basin. It is a large inland basin with a stable tectonic setting formed by the contraction of the North China Basin after the Indosinian movement. The Early and Middle Jurassic were divided into a sequence from the bottom to the top of the Fuxian Formation, the Yanan Formation, the Zhiluo Formation and the Anding Formation $^{[3]}$.

Identification of the system domain interface: The identification of the system domain interface mainly selects regional events. The first section of the Fuxian Formation and the Yanan Formation is the filling stage of the basin, and the coarse clastic rocks develop. The stratum changes greatly. The top 8 coal roof can be used as the initial lake surface. The lacustrine mudstone layer developed in a large area of the basin is the roof of the coal 4 layer, which represents the sedimentation of the largest lake intrusion and can be used as the largest lake surface $^{[4]}$.

\section{Identification marks of the study area sequence}

According to the existing data analysis, the Yanan Formation sedimentary sequence of the Yanan Formation in the Ningxian area of the basin is mainly composed of alluvial facies and delta facies ${ }^{[5]}$.

(1) Alluvial phase: from bottom to top, the particle size is from coarse to fine, taking the 1402 hole in the middle of Ningxian as an example.

Below the first section of the Yan'an Formation is the Upper Triassic gray-green, yellow-green sand mudstone. The top of the first section of the Yanan Formation is the second section of the Yanan Formation, which consists

\footnotetext{
* Corresponding author: Tai Xu, xutai871113@163.com
} 
of two small-scale spirals with a coarse and fine grain size from bottom to top. Because there is no large crustal movement and climate change during this period, they represent the spin-reduction formed by the migration of the diversion channel, which should be an alluvial phase.

Typical normal graded bed sequence sediments are sediments within the natural levees of the diversion channel, including stagnant deposits at the bottom and meandering sand dam deposits. The sediments in the floodplain outside the natural embankment are mostly thin-layer fine-grained sediments, and do not have the coarse-grained positive-grain order characteristics.

(2) Delta phase

The paper selects the small sequence at the bottom of the second section of the Yan'an Formation in the 1801 hole in the middle of Ningxian .

This is a type of bottom-up granularity that is thinner and thinner.

From the bottom up, the thinner and thicker part represents the delta frontal deposition. There is often a layer of mudstone at the bottom, which represents the deeper lake phase or front delta phase. The former delta facies are often thinned by the erosion of the overlying coarse-grained strata, and there is not much left. The bottom-up, thicker and thinner section above the formation represents the delta plain deposits.

\section{Sequence stratigraphic framework and its distribution in the study area}

\subsection{General characteristics of vertical sequence}

Starting from the study of sequence stratigraphy, Fuxian Formation and Yanan Formation are stratigraphic sequences separated by parallel unconformity(regional unconformity); the top boundary of the Yanan Formation was originally determined to be a parallel unconformity, which has recently been confirmed as a regional unconformity ${ }^{[6]}$.

The I unit (Yanan 1st formation) is mainly composed of a river sedimentary system, with one or two upwardlythinned river sedimentary sequences forming a braided river in the lower part and a meandering river in the upperpart. There is obvious swamping in the flood basin, forming a stable coal seam 8 . Due to the influence of the terrain, the partial section directly covers the unconformity of the Triassic.

Units II, III, and IV (Yan 2nd formation to Yan 4th formation) are generally lake and delta sequences. The coal mine 6, coal 4, coal 2 coal and the corresponding horizon are roof. Each unit contains 2 to 3 delta small sequences. Each small sequence represents the deposition process from the beginning of the lacustrine transgression-clastic flushing and filling(lake regression), abandoned-peat bog. The most obvious lake expansion occurs in the lower part of the II and III units. The I unit lake is mainly located in the east, and the lake surface is expanding from the east to the west from the II-IV unit lake. The distribution of coal seams is gradually decreasing (Table 1).
Table 1. Sequence stratigraphic unit table of Yan'an Formation in Ordos Basin

\begin{tabular}{|c|c|c|c|}
\hline stratum & Deposition & \multicolumn{2}{|c|}{ Sequence stratigraphic unit } \\
\hline \multirow[t]{3}{*}{ formation } & & parasequence sets & $\begin{array}{l}\text { System } \\
\text { domain }\end{array}$ \\
\hline & Delta & $\begin{array}{l}\text { Fifth parasequence } \\
\text { Alluvial system }\end{array}$ & $\begin{array}{l}\text { Refund } \\
\text { filling }\end{array}$ \\
\hline & Delta & $\begin{array}{l}\text { Fourth parasequence } \\
\text { Limited lake system }\end{array}$ & \\
\hline \multirow[t]{3}{*}{ yanan } & Delta & $\begin{array}{l}\text { Third parasequence } \\
\text { Open lake system }\end{array}$ & Overfill \\
\hline & $\begin{array}{l}\text { Delta } \\
\text { lake }\end{array}$ & $\begin{array}{l}\text { Second parasequence } \\
\text { Open lake system }\end{array}$ & \\
\hline & Alluvial & $\begin{array}{l}\text { First parasequence } \\
\text { Alluvial system }\end{array}$ & $\begin{array}{l}\text { Initial } \\
\text { filling }\end{array}$ \\
\hline fuxian & & & \\
\hline
\end{tabular}

\subsection{Sequence stratigraphic correlation and its distribution in the study area}

From the west to the east, it is seen from the comparison of the sequence stratigraphy of the ZhenyuanChenghuang Yanan Formation in the Longdong Coalfield: the thickness of the strata in the Fuxian Formation varies greatly, reflecting the fluctuation of the basement topography of the coal-bearing system. I, II, III (Yan 1st formation to Yan 3rd formation) are relatively stable, and the IV unit (Yan 4th formation) has a small thickness and is strongly denuded ${ }^{[7]}$.

From the south to the north, it is seen from the comparison of the sequence stratigraphy of the Nanliang-Ningxian Yanan Formation in the Longdong Coalfield: the thickness of the strata in the Fuxian Formation varies greatly, and there is no sedimentation in the middle of the Fuxian Formation, reflecting the fluctuation of the basement topography of the coal measures. The changes in the thickness of I, II, III (Yan 1st formation to Yan 3rd formation) reflect the structural background of apophyses alternating with depressions. The thickness of the south side of the IV unit (Yan 4th formation) is small, and the late uplift is strongly denuded $^{[8]}$.

\section{Coal seam comparison based on sequence stratigraphic analysis}

The formation of coal seams is the result of sufficient and stable supply of plant debris and continued accumulation of peat. In this process, the space available from the rising surface of the lake is one of the most important factors. If the surface of the lake rises too fast, the rate of increase in space can be too high, which will cause the peat to be submerged and unable to form a continuous accumulation. Conversely, if the surface of the lake rises too slowly and does not provide enough space for the accumulation of peat, it may cause peat exposure, weathering and cannot be formed continuous accumulation. Therefore, peat can only continue to accumulate when the overall growth rate of the 
allowable space and the peat accumulation rate is comparable or slightly faster.

Through the analysis of the sequence stratigraphic framework in this area, the distribution characteristics of the vertical coal seam are as follows: 8 layers of thick coal seams with stable distribution are formed at the initial lake invasion plane, and a stable distribution of coal seam coal can be formed at the maximum lake invasion plane. Between the coal 4 layer and the coal 8 layer, there is also a relatively extensive lacustrine transgression. The coal intrusion surface forms a relatively stable coal $6-1$, and the coal is distributed locally between coal 6-1 and coal 8 layers. The thickness of the 8th layer of coal at the initial lake surface is the largest, because the rate of peat accumulation in the area and the settlement rate of the basement are also roughly equal to the rising rate of the lake surface, so that a widely distributed thick coal seam can be formed.

According to the above-mentioned sequence stratigraphic framework law, the intrinsic relationship between the coal seams in the exploration areas such as Shajingzi, southern Zhengning, central Ningxian and southern Ningxian was found. The comparison between the coal seam number and the coal seam number of the original coal seam in each exploration area is shown in Table 2.

Table 2. Comparison of coal seam number in the different exploration area

\begin{tabular}{ccc}
\hline Location & $\begin{array}{c}\text { coal seam name of } \\
\text { mining coal seam } \\
\text { (Uniform numbers) }\end{array}$ & $\begin{array}{c}\text { coal seam name of } \\
\text { mining coal seam } \\
\text { (Uniform numbers) }\end{array}$ \\
\hline Middle of & coal 4, coal 6-1, & coal1-1, coal3-1, \\
Shajingzi & coal 6-2, coal 8 & coal4-1, coal5-1 \\
South of & coal4,coal6-1, & coal2, coal5, \\
Zhengning & coal8 & coal8 \\
Middle of & coal4, coal6-1, & coal2, coal5, \\
Ningxian & coal6-2, coal8 & coal6, coal8 \\
South of & coal4, coal6-1, coal8 & coal2, coal5, coal8 \\
Ningxian & & \\
\hline
\end{tabular}

\section{Conclusion}

The Ordos Basin is a large Mesozoic large-scale coalbearing basin. In the late 1980s, Li Sitian and Li Baofang completed the study of sequence stratigraphy and sedimentary systems in the northeast and central parts of the Ordos Basin. However,The Longdong coalfield (the southwestern margin of the Ordos Basin) is still blank in the analysis of sequence stratigraphy.In this paper, the geological data obtained from the geological exploration of coal fields in the eastern part of the country have been used. This paper used nearly 300 drilling data and logging curves, five long sections (through the coal field) and dozens of short sections. Through the division of the vertical sequence,the comparison of the longitudinal and transverse sections along with the analysis of the distribution law on the plane, the following results were obtained:

(1) A clear understanding of the vertical distribution of coal seams in the sequence stratigraphic framework in the Longdong Basin has been made. It is determined that there are four layers of recoverable coal seams from top to bottom in the coal field: coal 4, coal 6-1, coal 6-2, coal 8 floor.

(2) The plane distribution law of the coal seams in the sequence stratigraphic framework in the Longdong Basin is clarified, which is of great significance for solving the coal seam comparison problem between different exploration areas in the Longdong coalfield.

(3) The plane distribution law of the coal seams in the sequence stratigraphic framework in the Longdong Basin is clarified, which is of great significance for solving the coal seam comparison problem between different exploration areas in the Longdong coalfield.

\section{Acknowledgement}

This work was financially supported by youth science and technology innovation funding project of Longdong college (XYZK1808), youth science and technology fund project of Gansu province (18JR3RM240), Higher education project of gansu province (2018A-097), research projects of safety production in Gansu province (GAJ00011,GAJ00017),science and technology program funding project of Gansu province (17JR5RM355).

\section{References}

1. Wu Mingjun, Xu Xia, Cao Xueming, el at. Coal No.8 Reservoir Characteristics and CBM Exploration Prospect Analysis in Longdong Area, Gansu Province [J]. Coal Geology of China, 26(2014) : 28-32

2. Xu Tai, Li Yanju, Yang Fengfeng, el at. Comparative Analysis of Coal Seam in Liuyuanzi Mine Field in Longdong Area [J]. Mineral Engineering Research, 33(2018) : 64-68

3. ZHANG Hong, Bai Qingzhao, ZHANG Xiaowei, el at. The formation and tectonic environment of Ordos Basin [J]. Coal Geology and Exploration, 23 (1995) : $1-9$

4. Cao Daiyong, Xu Hao, LIU Kang, el at. Coalfield tectonic evolution and its controlling factors at the western margin of Ordos Basin [J]. Chinese Journal of Geology, 50 (2015): 410-427

5. Xu Hao, Liu Jincheng, Liu Kang, el at. Study on CBM Reservoiring Condition in Ordos Basin Western Margin [J]. Coal Geology of China, 27(2015) : 37-42

6. Cao Dawen, Tian Xiurong, Pu Lijun. Main Coalforming Stage Lithofacies, Paleogeography and Coal Accumulation Characteristics in Ningzhong Mine Area, Qingyang, Gansu [J]. Coal Geology of China, 26 (2014) : 36-39

7. Wang Baoyu, Li Youyi. Geochemistry of water from coalbed methane wells and the analysis of gas drainage in the Xifeng Mining District, Gansu Province [J]. Geological Journal of China Universities, 18(2012) : 579-582

8. Cao Daiyong, Liu Kang, Liu Jincheng, el at. Combination characteristics of unconventional gas 
in coal measure in the west margin of Ordos Basin [J]. Journal of China Coal Society, 41(2016) : 277285 